\title{
Metal Concentration in Plant Tissues of Ricinus communis L. (Castor Oil) Grown In Soil Contaminated With Spent Lubricating Oil
}

\author{
*VWIOKO, D E; ANOLIEFO GO; FASHEMI, S D
}

\author{
Dept. of Botany, Faculty of Science, University of Benin, Benin City, Nigeria
}

\begin{abstract}
Castor oil plant seeds (Ricinus communis L.) were grown in spent lubricating oil (SLO) contaminated soil at concentrations of $1-6 \%(w / w, ~ o i l / s o i l)$. Plant height and stem girth were depressed by spent lubricating oil at concentrations of $2 \%(\mathrm{w} / \mathrm{w})$ and above. One percent $(1 \%)$ spent lubricating oil in soil promoted growth of plants when compared with control. Fresh and dry weights of $R$. communis plants grown in $1 \%$ oil treatment were significantly more than that of control. Spent lubricating oil in soil depressed $\mathrm{pH}$. From the values obtained for metal concentrations in leaves, stems and roots, the concentrations of manganese and nickel were highest in the leaves. At 2\% SLO and above, lead concentration was highest in the leaves too. Accumulation of the metals by plant parts were not concentration dependent. Specifically metal accumulation in $R$. communis, in the present study showed that $\mathrm{Mn}, \mathrm{Ni}$ and $\mathrm{Pb}$ were mostly accumulated in the leaves; while $\mathrm{V}$ was highest in roots. @JASEM
\end{abstract}

Oil pollution of soil leads to the build up of essential (organic carbon, $\mathrm{P}, \mathrm{Ca}, \mathrm{Mg}$ ) and non-essential ( $\mathrm{Mn}$, $\mathrm{Pb}, \mathrm{Zn}, \mathrm{Fe}, \mathrm{Co}, \mathrm{Cu}$ ) elements in soil and the eventual translocation in plant tissues. The pollution of soil by spent lubricating oil has been reported to cause growth retardation in plants (Anoliefo and Vwioko, 1995; Odjegba and Sadiq, 2002). This reduction in plant growth has been attributed to the presence of heavy metals at toxic concentrations in soil (Anoliefo and Vwioko,1995). Whismann et al. (1974) observed that most heavy metals such as vanadium, lead, aluminium, nickel and iron, which were usually below detection in unused lubricating oil, gave high ppm values in used oil. Elements such as $\mathrm{Cu}, \mathrm{Mo}, \mathrm{Ni}$, $\mathrm{Mn}, \mathrm{Cl}$ and $\mathrm{Zn}$ are essential for plant growth in low concentrations (Reeves and Baker, 2000). Nevertheless, beyond certain concentrations, these same elements become toxic for most plant species (Monni et al., 2000).

Metals in plant tissues may have two principal origins: absorption from soil and deposition from the atmosphere. A few higher plant species have adaptations that enable them survive and reproduce in soils that are heavily contaminated with $\mathrm{Zn}, \mathrm{Cu}, \mathrm{Pb}$, $\mathrm{Cd}$, and Ni (Baker, 1987). Such species are divided into two main groups: the so-called Pseudometallophytes that grow on both contaminated and non-contaminated soils and the absolute metallophytes that grow only on metal-contaminated and naturally metal-rich soils (Baker, 1987). Uptake of metals by plants is affected by several factors including the type and age of plant, type of soil, $\mathrm{pH}$ of soil, organic matter content of the soil, redox potential, cation exchange capacity of soil, surface area and texture of soil particles, the presence and concentration of foreign ions, growth rate and growth conditions (Salim et al., 1993). Depending on plant

Correspondence: **Email: vwioko@yahoo.com, +234-80-5596-6903 *Email: obidimbu@yahoo.com, +234-80-2381-3379 species, metal tolerance may result from two basic strategies: metal exclusion and metal accumulation (Baker and Walker, 1990). The exclusion strategy comprises avoidance of metal uptake and restriction of metal transport to the shoots (De Vos et al., 1991). This strategy is used by pseudometallophytes. These plants are used to re-vegetate bare soil areas, where the lack of vegetation results from excessively high metal concentration. The accumulation strategy consists of high concentration of metals in plants tissues.

Plant species vary in their capacity to remove and accumulate heavy metals (Zurayk et al., 2001). Differences also exist among plants as to whether the removed metal is accumulated in the root or translocated to the shoot. Nevertheless, some metals have been observed to show characteristic physiological fates. For example, $\mathrm{Pb}$ is accumulated more in roots than any other part of the plant; $\mathrm{Cu}$ and $\mathrm{Ni}$ are accumulated in roots and shoots (Salim et al., 1993). The plants act as diffuse samplers, accumulating pollutants to a higher concentration than their surroundings. This is as a result of continuous absorption of minerals over time (Zurayk et al., 2001).

The objective of the study was to evaluate the species ability to accumulate $\mathrm{Mn}, \mathrm{Ni}, \mathrm{Pb}$ and $\mathrm{V}$ in different parts of the plant - viz leaf, stem and root. Also to give suggestion on the physiological fates of the metals when $R$. communis is grown in spent lubricating oil (SLO) contaminated soil.

\section{MATERIALS AND METHODS}

Soil collection: The soil used in the study was obtained as a composite (pooled) sample of top soil (0 $-20 \mathrm{~cm}$ depth), in the University of Benin Teaching 
and Research Farm Benin City (Lat. $6^{0} .5^{1} \mathrm{~N}$, Long $\left.5^{0} 5^{1} \mathrm{E}\right)$. The soil is reddish brown acid sand; commonly referred to as Benin Fasc (Ogunkunle, 1983). Data of the physicochemical properties of this soil were reported by Orhue and Osaigbovo (2003) as shown in Table 1(a \& b). Soil treatment was carried out before seeds were sown.

Table 1a: Physico-chemical data obtained from analysis of experimental soil, before and after treatment with spent lubricating oil (SLO). Data obtained from Orhue and Osaigbovo (2003).

\begin{tabular}{cccccccc}
\hline & $\mathrm{pH}$ & $\% \mathrm{C}$ & $\% \mathrm{~N}$ & $\mathrm{P}(\mathrm{ppm})$ & \multicolumn{3}{c}{ Particle Size Analysis (\%) } \\
\hline & & & & & clay & silt & sand \\
Soil (BP) & 5.59 & 2.68 & 0.20 & 3.14 & 4.30 & 3.70 & 92.00 \\
Soil (AP) & 5.60 & 3.80 & 0.20 & 8.00 & 3.60 & 4.80 & 92.60 \\
& \multicolumn{1}{c}{$\mathrm{pH}=1: 1($ soil: water) } \\
$\mathrm{BP}=$ Before Pollution, AP = After Pollution. Pollution was 10\% v/w (spent lubricating oil to soil).
\end{tabular}

Table 1b: Chemical data obtained for analysis of experimental soil, before and after treatment with spent lubricating oil (SLO). Data obtained from Orhue and Osaigbovo (2003).

\begin{tabular}{ccccccccc}
\multicolumn{7}{c}{ obtained from Orhue and Osaigbovo (2003). } \\
\cline { 2 - 8 } & $\mathrm{Na}$ & $\mathrm{K}$ & $\mathrm{Ca}$ & $\mathrm{Mg}$ & $\mathrm{H}^{+}$ & $\mathrm{Al}^{3+}$ & $\mathrm{ECEC}$ \\
\hline Soil(BP) & 0.59 & 0.76 & 1.86 & 1.20 & 0.10 & 0.03 & 4.51 \\
Soil(AP) & 0.41 & 0.50 & 0.90 & 0.51 & 0.11 & 0.05 & 3.58 \\
\hline
\end{tabular}

Soil Treatment: Soils of known weight $(5 \mathrm{~kg})$ were each treated with different concentrations (1, 2, 3, 4, 5 and $6 \%$ weight of oil/weight of soil) of spent lubricating oil (SLO). The soil samples were thoroughly mixed with the SLO by hand to get a homogenous mixture. Each soil sample was put in perforated polythene pots measuring $20 \mathrm{~cm} \times 50 \mathrm{~cm}$, and each treatment including control ( $0 \%$ SLO) was replicated four times. The pots were later transferred to the field.

Spent lubricating oil: This was obtained as pooled, used engine oil from motor mechanics at different locations in Benin City.

Seed collection and treatment: Dried seeds of $R$. communis (castor oil plant) were obtained from a fallow farmland in Benin City, Nigeria. The viable seeds determined by flotation were soaked in water for twelve (12) hours before sowing.

Planting and Harvest: Twelve (12) seeds of $R$. communis were sown in each pot at a depth of $3 \mathrm{~cm}$. The pots were watered as and when necessary. Three weeks after emergence, seedlings were thinned to 2 per pot. The experiment was terminated ninety-six (96) days after planting. At harvest, the plants were carefully uprooted. The plant roots were gently teased to remove soil particles. They were gently dipped in a bucket of water and rinsed twice with distilled water to remove attached soil particles. The plants were oven-dried at $80^{\circ} \mathrm{c}$ for 3 days to obtain dry weights of root and stem.
Experimental design: The experiment was designed as a completely randomized one. One-way Analysis of variance (ANOVA) was carried out to compare the means of different treatments. Where significant $F$ values were obtained and differences between individual means were tested using the LSD test.

Plant Tissue Analysis for Metals: Oven-dried root, stem and leaf parts were ground using an electricity powered blender (mill) to powdered state. One gram (1g) of tissue sample was weighed into beakers and put in a muffle furnace for ashing at $550^{\circ} \mathrm{C}$ for 5 hours. The ashed materials were allowed to cool. Ten millitre $(10 \mathrm{ml})$ of $20 \% \mathrm{HNO}_{3}$ was dispensed into each beaker containing the ashed samples. The mixture was warmed on a hot plate for $15 \mathrm{mins}$ and stirred with a glass rod to enable it dissolve. After complete digestion, the solutions were allowed to cool, and made up to $50 \mathrm{ml}$ with distilled water. AAS measurements for metals were carried out.

Soil pH Measurement: This was determined in distilled water and $0.01 \mathrm{M} \mathrm{CaCl} \mathrm{Ca}_{2}$ solution (soil to liquid mixture $=1: 3$ ). The mixture was stirred for 5 mins. and allowed to stand for one hour before measurement using a $\mathrm{pH}$ meter with electrode (Jenway 3020).

Soil Chemical Analysis: Soil samples (10g each) of each SLO treatment were air-dried for two weeks and later sieved. Digestion of soil was done using the double acid (a combination of $\mathrm{H}_{2} \mathrm{SO}_{4}$ and $\mathrm{HCl}$ ) method for available heavy metals. $0.025 \mathrm{M}$ of the double acids was prepared as the extraction solution. Six gram $(6 \mathrm{~g})$ of soil samples were weighed into a beaker and $60 \mathrm{ml}$ of extraction solution added. The 
mixture was shaken using a mechanical shaker for 1 hour and allowed to stand for another 30mins. The solutions were collected in plastic bottles for AAS determination of $\mathrm{Mn}, \mathrm{Ni}, \mathrm{Pb}$ and $\mathrm{V}$.
The values for $\mathrm{Mn}, \mathrm{Ni}, \mathrm{Pb}$ and $\mathrm{V}$ in soil obtained before planting and after treatment with spent lubricating oil (SLO) are shown in Table 2. Results for $\mathrm{Mn}$ indicate increase in metal in soil after pollution

\section{RESULTS}

Table 2: Concentration (ppm) of $\mathrm{Mn}, \mathrm{Ni}, \mathrm{Pb}$ and $\mathrm{V}$ in soil contaminated with spent lubricating oil (SLO) before plant growth (mean $\pm \mathrm{S} . \mathrm{D}$.)

\begin{tabular}{ccccc}
\hline & \multicolumn{4}{c}{ Metal concentration (ppm) } \\
\hline SLO in soil (\%) & $\mathrm{Mn}$ & $\mathrm{Ni}$ & $\mathrm{Pb}$ & $\mathrm{V}$ \\
0 & $27.37 \pm 2.51$ & $0.17 \pm 0.05$ & $0.10 \pm 0.03$ & $0.10 \pm 0.04$ \\
1 & $37.03 \pm 4.05$ & $0.41 \pm 0.11$ & $0.56 \pm 0.12$ & $0.25 \pm 0.09$ \\
2 & $36.47 \pm 6.11$ & $0.49 \pm 0.21$ & $0.31 \pm 0.17$ & $0.21 \pm 0.11$ \\
3 & $31.87 \pm 6.05$ & $0.39 \pm 0.23$ & $0.39 \pm 0.20$ & $0.18 \pm 0.07$ \\
4 & $34.22 \pm 8.00$ & $0.38 \pm 0.16$ & $0.37 \pm 0.19$ & $0.23 \pm 0.08$ \\
5 & $35.19 \pm 7.12$ & $0.43 \pm 0.04$ & $0.46 \pm 0.15$ & $0.26 \pm 0.07$ \\
6 & $36.91 \pm 5.31$ & $0.34 \pm 0.11$ & $0.35 \pm 0.13$ & $0.21 \pm 0.08$ \\
\hline
\end{tabular}

Fig 1 shows the results obtained for plant tissue analysis of Mn for root, stem and leaves of $R$. communis. The Mn values were highest in the leaves followed by stem and the root.

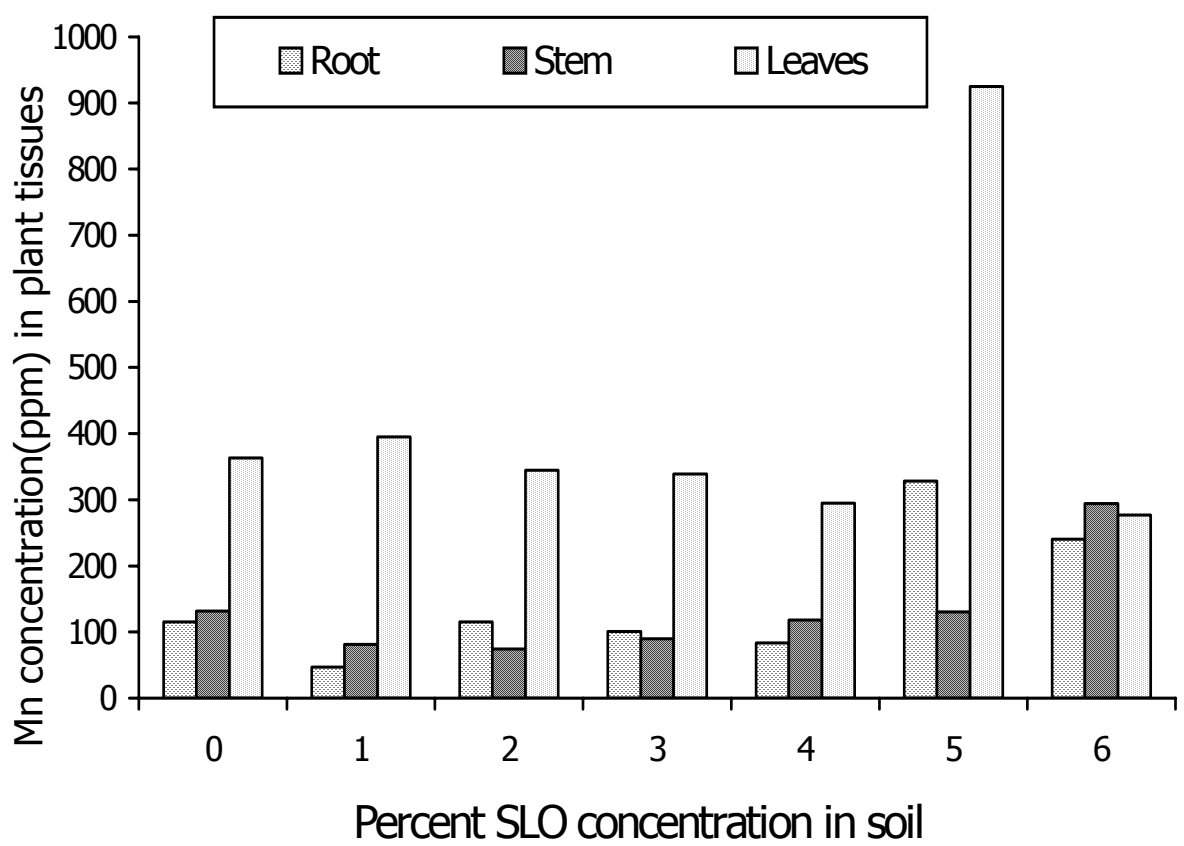

Fig. 1: Manganese (Mn) concentration in root, stem and leaves of Ricinus communis L. (castor oil) plants after 96 days of growth in spent lubricating oil (SLO) contaminated soil

Fig 2 shows the results obtained for plant tissue concentration of $\mathrm{Ni}$ in root, stem and leaves. For plant tissues in $0 \%$ SLO, Ni concentration was highest in leaves, followed by stem and then root. At 1 and $5 \%$
SLO, Ni concentration showed leaves $>$ root $>$ stem. Differences in Ni concentration in leaves of plants in $1 \%, 2 \%, 3 \%$ and $4 \%$ were not significant. 


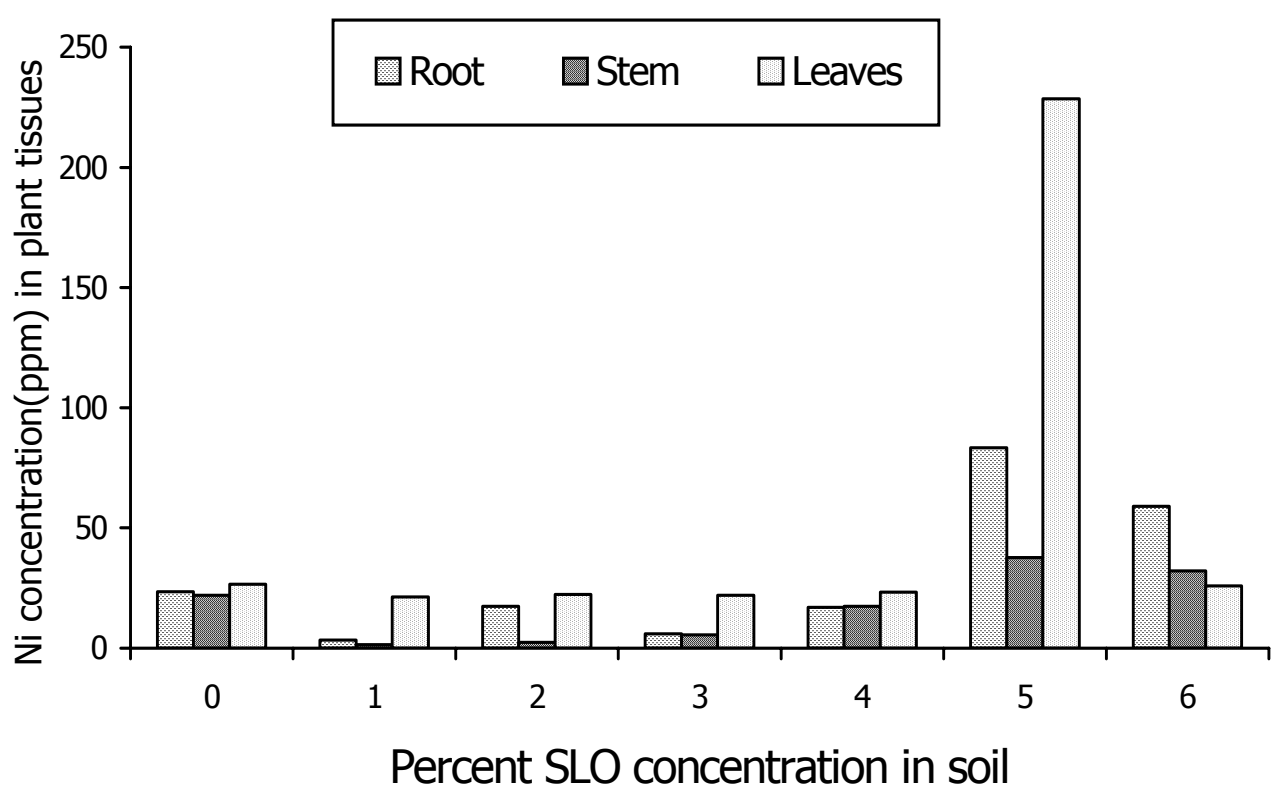

Fig. 2: Nickel (Ni) concentration in roots, stems and leaves of Ricinus communis L. (castor oil) plants after 96 days of growth in spent lubricating oil (SLO) contaminated soil

Figure 3 shows the values obtained for plant tissue concentration of $\mathrm{Pb}$ in root, stem and leaves. At $0 \%$ $\mathrm{SLO}, \mathrm{Pb}$ concentration showed root $>$ leaves $>$ stem. At $1 \% \mathrm{SLO}$, the $\mathrm{Pb}$ concentration showed that root $>$ stem $>$ leaves. At $5 \%$ SLO, the pattern was that leaves
$>$ root $>$ stem. Again $\mathrm{Pb}$ concentrations in all tissues tested gave higher values for $5 \%$ than in $6 \%$ SLO, and their differences were significant. Lead $(\mathrm{Pb})$ concentration in root, stem and leaves was concentration dependent

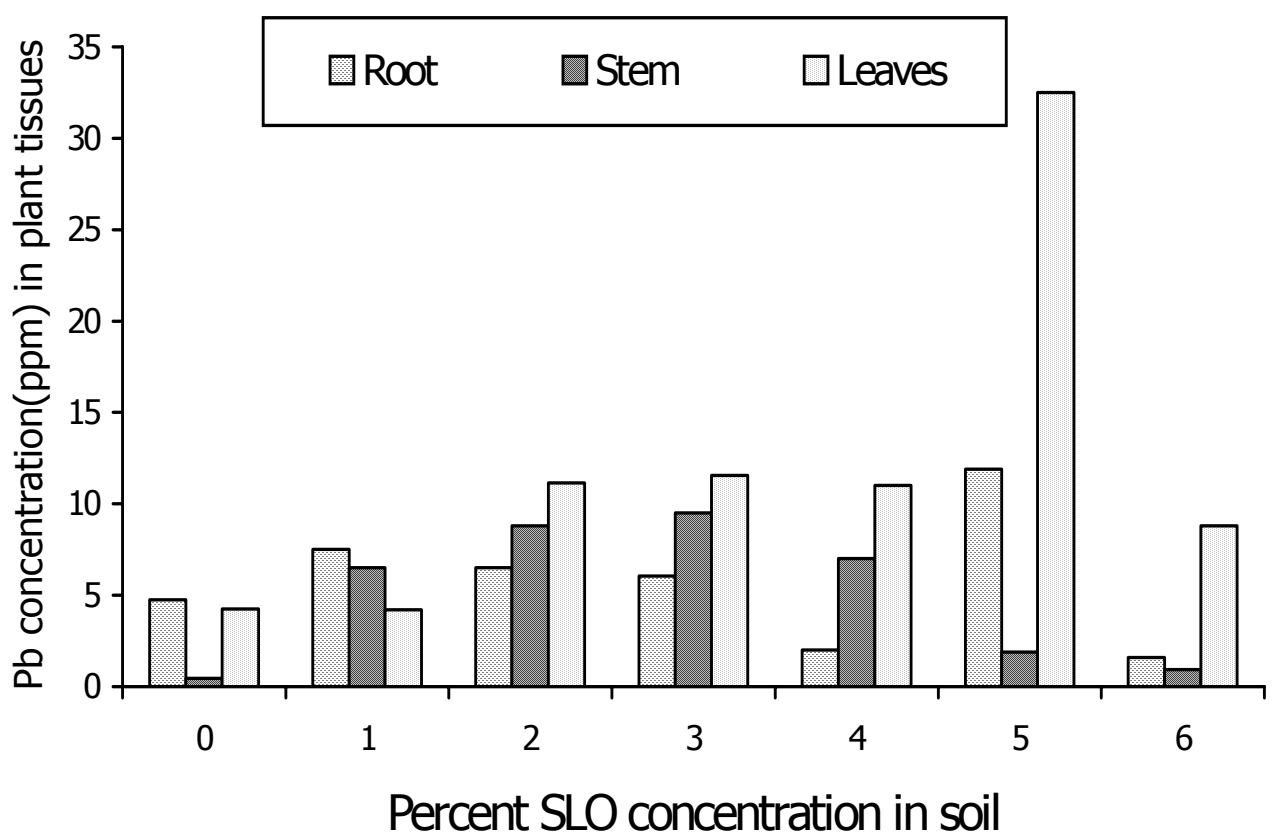

Fig. 3: Lead $(\mathrm{Pb})$ concentration in roots, stems and leaves of Ricinus communis L. (castor oil) plants after 96 days of growth in spent lubricating oil (SLO) contaminated soil

Figure 4 shows the results obtained for plant tissue concentration of vanadium in root and stem. At $0 \%$
SLO, V concentration was higher in root than stem. The $\mathrm{V}$ concentration values for root and stem at $1 \%$ 
SLO were much less than those obtained for $0 \%$ SLO (control). At 2\% SLO, the pattern was root $>$ stem and at 3\% SLO, the values were close and difference was insignificant. The highest values for $\mathrm{V}$ concentrations were recorded for plant tissues at 5\% SLO. These values were higher than those obtained for $0 \%, 1 \%, 2 \%, 3 \%$, and $4 \%$ SLO. Generally, V concentrations were higher in root than stem. The concentrations of vanadium in leaves were not assayed for due to lack of recent reports or literature on uptake of vanadium in plants and financial constraints.

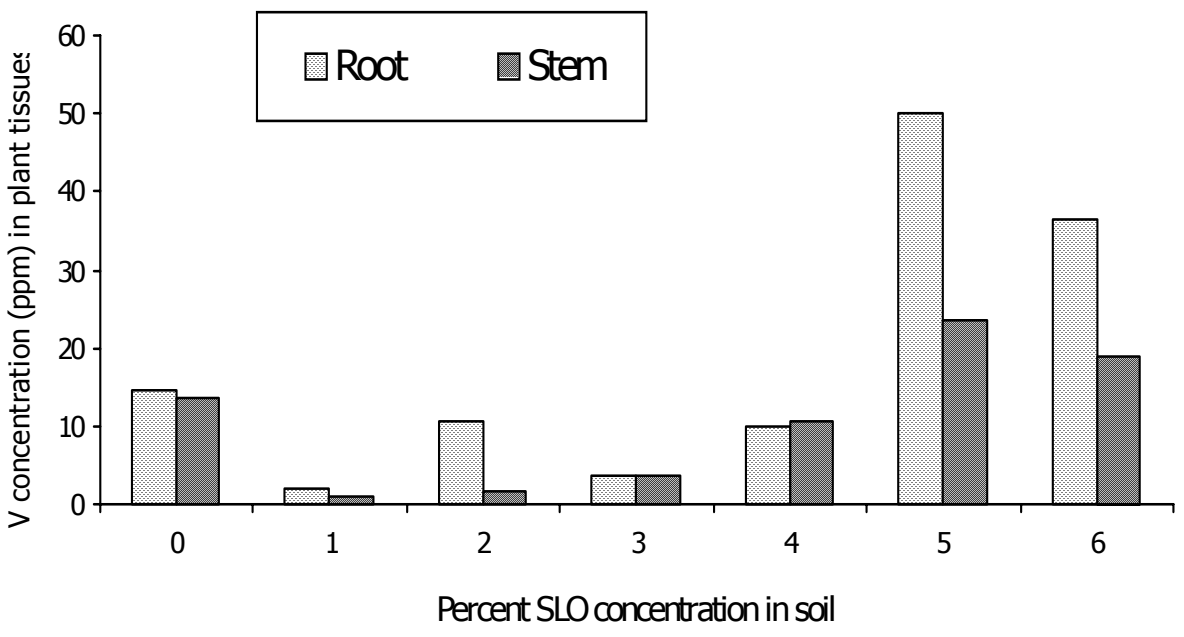

Fig. 4: Vanadium (V) concentration in roots and stems of Ricinus communis L. (castor oil) plants after 96 days of growth in spent lubricating oil (SLO) contaminated soil

\section{DISCUSSION}

Metal Concentration in Soil and Plant Growth: The result of soil analysis obtained in this study showed increase in the concentration of $\mathrm{Mn}, \mathrm{Ni}, \mathrm{Pb}$, and $\mathrm{V}$ in soil contaminated by spent lubricating oil (SLO). This may have accounted for the reduction in mean $\mathrm{pH}$ values of soil which were below 5.28 and 4.76 for control $\left(0 \%\right.$ SLO) in distilled and $0.01 \mathrm{M} \mathrm{CaCl}_{2}$ solution respectively (Table 3 ).

Table 3: Mean $\mathrm{pH}$ values of spent lubricating oil contaminated soil in distilled water and $0.01 \mathrm{M} \mathrm{CaCl}_{2}$ solution

\begin{tabular}{ccc}
\hline \multicolumn{3}{c}{ Mean $\mathrm{pH}$ values } \\
\hline SLO concentration in soil & Distilled water (soil : $\left.\mathrm{H}_{2} \mathrm{O}=1: 3\right)$ & $0.01 \mathrm{M} \mathrm{CaCl}_{2}\left(\right.$ soil $\left.: \mathrm{CaCl}_{2}=1: 3\right)$ \\
0 & 5.28 & 4.76 \\
1 & 5.09 & 4.56 \\
2 & 4.96 & 4.38 \\
3 & 5.04 & 4.46 \\
4 & 4.90 & 4.36 \\
5 & 4.83 & 4.19 \\
6 & 4.82 & 4.18 \\
\hline
\end{tabular}

The metal concentration of soil did not increase as the concentration of SLO in the soil increased. Plant growth in the different soil media showed differences in level of toxicity (data not reported here). The chemical extraction procedure may not have efficiently shown this difference in toxicities as SLO concentration increased. At concentration of SLO in soil greater than $1 \%$, there were depressions on plant growth as SLO concentration in soil increased. The data obtained for the soil chemical analysis showed that the effects observed for plants in 2\% SLO and above may not have been as a result of acid extractable metallic concentrations. These may be due to other constituents (hydrocarbon, grease) and soil conditions the higher SLO concentrations created within the soil media (see Table 4). Reduced shoot growth and water use efficiency in barley growing in soil contaminated by crude oil was attributed to low soil water potential (Li et al, 1997). Malallah et al., (1996) recorded a decrease in biomass and moisture content of Vicia faba plants grown in oil polluted soil containing an elevated level of salt. The $\mathrm{pH}$ values in this study showed that the soil became more acidic as the concentration of SLO increased. 
Table 4: The leaf/root metal concentration quotation $\left(\mathrm{M}_{\mathrm{L}} / \mathrm{M}_{\mathrm{R}}\right)$ in the SLO concentration studied.

\begin{tabular}{cccc}
\hline & & & \\
$\mathrm{M}_{\mathrm{L}} / \mathrm{M}_{\mathrm{R}}$ & & & \\
\hline SLO concentration & $\mathrm{Mn}$ & $\mathrm{Ni}$ & $\mathrm{Pb}$ \\
0 & 3.157 & 1.130 & 0.895 \\
1 & 8.415 & 6.114 & 0.560 \\
2 & 2.983 & 1.280 & 1.715 \\
3 & 3.356 & 3.667 & 1.909 \\
4 & 3.533 & 1.371 & 4.511 \\
5 & 2.815 & 2.742 & 2.73 \\
6 & 1.151 & 0.439 & 4.812 \\
\hline
\end{tabular}

The acidic condition of the soil as observed from $\mathrm{pH}$ measurement increased the availability of heavy metals to plants. Most heavy metals are available to plant roots in acidic medium. Plant biomass (fresh and dry weights) data showed that the highest value obtained was at $1 \%$ SLO. The deduction was that the $1 \%$ SLO concentration promoted plant growth about $418 \%$ of control (Table 5).

Table 5: Fresh and dry weights (g) of $R$. communis plants after 96 days of growth in spent lubricating oil contaminated soil.

\begin{tabular}{ccc}
\hline SLO concentration in soil & Fresh weight $(\mathrm{g})$ & Dry weight $(\mathrm{g})$ \\
\hline 0 & $155.00 \pm 12.73$ & $67.00 \pm 2.64$ \\
1 & $647.70 \pm 498.22$ & $312.50 \pm 265.17$ \\
2 & $141.05 \pm 76.44$ & $49.09 \pm 1.29$ \\
3 & $77.50 \pm 88.39$ & $25.11 \pm 24.39$ \\
4 & $45.95 \pm 6.15$ & $17.37 \pm 4.31$ \\
5 & $36.50 \pm 9.19$ & $8.64 \pm 0.95$ \\
6 & $18.35 \pm 2.33$ & $9.05 \pm 1.18$ \\
\hline \multicolumn{3}{c}{ Figures $=$ mean \pm S.D. }
\end{tabular}

Higher SLO concentration gave lower values for biomass (i.e. depressed growth by $9-88 \%$ of control) due to increasing stress from soil contaminant. Any condition that disrupts the normal plant water relation of the roots within the soil would negatively affect the normal growth of the plant (Epstein, 1972). The result suggested that greater disruption took place at SLO concentration higher than $1 \%(\mathrm{w} / \mathrm{w})$.

Metal Concentrations in Plant Tissues: The data obtained in the study showed that the concentration of $\mathrm{Mn}, \mathrm{Ni}, \mathrm{Pb}$ and $\mathrm{V}$ were considerably higher in plant tissues than soil concentrations. It may indicate that the plant is capable of removing the metals from the soil matrix. It would also show that removed metal are translocated from the root to the shoots and leaves in a similar fashion as hyper-accumulator species. The study has shown that Ricinis communis can grow in SLO concentration of up to $6 \%(\mathrm{w} / \mathrm{w}$; oil $/ \mathrm{soil})$ and is able to accumulate metals like $\mathrm{Mn}, \mathrm{Ni}, \mathrm{Pb}$ and $\mathrm{V}$ from SLO contaminated soil. The highest Mn concentration was obtained in the leaf samples. The values obtained for root ranged between 40 and 330ppm, stem was 72 - 295ppm and leaf was 275 - 930ppm (Figure 1). The highest values of Mn concentration were obtained in 5 and $6 \%$ SLO concentration. A significant feature of the data obtained for Mn concentration in tissues was that greater proportion of $\mathrm{Mn}$ absorbed by the root was translocated to the leaves. This suggests an unrestricted internal transport with sap through stem to leaves. Under acid conditions as indicated by $\mathrm{pH}$ measurement, $\mathrm{Mn}$ is sufficiently soluble in soil.

Nickel uptake and accumulation in $R$. communis was similar to manganese, as the highest Ni concentrations were observed in the leaves. The range of $\mathrm{Ni}$ concentration in root was $3.50-83.33 \mathrm{ppm}$, stem was $1.50-37.74 \mathrm{ppm}$, and leaves $21-228.50 \mathrm{ppm}$. The highest concentration for $\mathrm{Ni}$ in the three tissues was obtained at 5\% SLO treatment. Also, tissue concentrations of nickel for control ( $0 \%$ SLO) were higher than $1 \%$ SLO in the three tissues. The data on tissue concentration of $\mathrm{Ni}$ showed that greater proportion of nickel absorbed by the root was translocated to the leaves. Nickel uptake is enhanced in acidic soils. Nickel uptake and concentration in plant foliage can differ markedly between species even in the same soils. Hutchinson and Whitby (1974) reported concentrations of $902 \mathrm{ppm} \mathrm{Ni}$ in the grass Deschampsia flexuosa and 92ppm Ni in the foliage of Vaccinium augustifolium at the same site. In the latter species ( $V$. augustifolium) Bagatto and Shorthouse (1991) reported that the pattern of $\mathrm{Ni}$ accumulation was roots $<$ stems $<$ leaves $<$ berries. They suggested that factors which account for this trend were the general non-essentiality of $\mathrm{Ni}$ as a plant nutrient, its greater mobility within a plant and its greater availability in acidic soils.

$\mathrm{Pb}$ was taken up by $R$. communis plants grown in spent lubricating oil contaminated soil. $\mathrm{Pb}$ was detected in all the tissues examined (root, stem and leaves). Pichtel et. al. (2000) reported that soil $\mathrm{Pb}$ was taken up in substantial quantities by herbaceous and woody species grown in contaminated sites. Seventy percent of species tested contained higher root $\mathrm{Pb}$ compared to shoot $\mathrm{Pb}$, indicating limited mobility once absorbed by the roots. In plants exposed to leadcontaminated rooting media, the roots always contained lead concentrations considerably greater than other above ground tissues (Koeppe, 1981); and that lead is bound to the roots where such binding serves to protect the remaining plant parts from injury. The movement or translocation of lead from absorbing roots or root hairs is apparently impeded by a number of biochemical and /or physical processes involving lead binding, inactivation and /or 
precipitation (Koeppe, 1981). In this study, $\mathrm{Pb}$ concentration in tissues ranged from $2.00-11.90 \mathrm{ppm}$ in root, $0.45-9.50 \mathrm{ppm}$ in stem and $4.20-32.50 \mathrm{ppm}$ in leaves. The $\mathrm{Pb}$ concentration pattern generally was leaves $>$ root $>$ stem. At $0 \%$ (control) SLO, Pb concentration was $4.75 \mathrm{ppm}$ in roots, $0.45 \mathrm{ppm}$ in stem and $4.25 \mathrm{ppm}$ in leaves. For $2-6 \%$ SLO in soil, the highest concentration of $\mathrm{Pb}$ in tissue was obtained in leaves (Figure 3). This was contrary to reports by Pichtel et al., (2000) and Pichtel and Salt (1998). The data obtained in this study showed that at SLO concentration greater than $1 \%$, there was translocation of $\mathrm{Pb}$ from the roots to the leaves. This may indicate a tolerance mechanism by $R$. communis. DahmaniMuller et. al. (2000) reported that Cardaminopsis halleri plants grown near a smelter showed $\mathrm{Pb}$ concentration in tissues pattern as leaves $>$ stems $>$ roots. $\mathrm{Pb}$ concentration in leaves and stems were 7 and 1.5 times higher respectively. The data suggest that $\mathrm{Pb}$ uptake and transport were not immobilized in roots. A diffusion mechanism may allow $\mathrm{Pb}$ to be transported with sap to stems and leaves. Miller and Koeppe (1971) demonstrated that Zea mays L. plants translocated and accumulated significant quantities of $\mathrm{Pb}$ in the leaves in a concentrated dependent manner. Jarvis and Leung(2002) stated that the combination of chelating agents (such as H-EDTA or EDTA) and low $\mathrm{pH}$ prevented root cell wall retention of lead $(\mathrm{Pb})$ making $\mathrm{Pb}$ available for translocation to shoots.

Substantial amount of vanadium occur in crude oil and petroleum ash. The element is also found in certain ores and oil shales. Crude oils have been found to contain up to $144 \mathrm{ppm}$ vanadium: Venezuelean oils are noted to be particularly rich in the metal (Bengtsson and Tyler, 1976). Most plants accumulate vanadium in very small amounts from the soil in relation to the total soil content. Tolerance of high amounts of vanadium in plants is due to immobilization of the element as an insoluble product in the root, partial exclusion mechanisms also prevent uptake of the element from enriched soils (Peterson and Girling, 1981). High calcium soils restrict movement of vanadium into the plant root. Generally, higher concentration of vanadium was obtained in root tissues compared to stem tissues (Figure 4). The data obtained showed that $\mathrm{V}$ concentration of $0 \%$ SLO (control) root and stem tissue were higher than that of $1-4 \%$ SLO root and stem. While 5 and $6 \%$ SLO V concentrations gave 3.4 and 2.5 times that of control respectively; and in stem about 1.7 and 1.4 times respectively. The lower values obtained for 1 $4 \%$ SLO compared to control may be due to other soil factors or metals which hindered the uptake of $\mathrm{V}$ (Figure 4). The study showed that $R$. communis accumulate $\mathrm{V}$ in root. Other plant species reported to tolerate vanadium above $100 \mathrm{ppm}$ were Astragalus spp, Allium macropetalum, Castillega augustifolia and Chrysothamnus viscidiflorus (Peterson and Girling, 1981). These species are used as indicators of vanadium deposits.

The data on tissues concentration of metals obtained in this study showed that the highest metal concentration in all tissues of Ricinus communis was found at 5\% SLO (Figures 1-4). We suggest that this $5 \%$ SLO in soil represent the concentration of spent lubricating oil at which metal accumulation by $R$. communis is maximum.

From the leaf/root metal concentration quotients $\left(\mathrm{M}_{\mathrm{L}} /\right.$ $\mathrm{M}_{\mathrm{R}}$ ) calculated for $R$. communis grown in SLO showed that greater proportion of $\mathrm{Mn}, \mathrm{Ni}$ and $\mathrm{Pb}$ absorbed were translocated to the leaves as a tolerance strategy (Table 4). This suggests that metal immobilization in roots (an exclusion strategy) is less efficient in Ricinus communis growing in spent lubricating oil polluted soil and consequently the aforementioned metals are transported to the leaves by diffusion.

\section{REFERENCES}

Anoliefo, G O ; Vwioko, D E (1995). Effects of spent lubricating oil on the growth of Capsicum annum L. and Lycopersicon esculentum Mill. Environmental Pollution 88: 361-364.

Bagatto, G ; Shorthouse, J D (1991). Accumulation of $\mathrm{Cu}$ and $\mathrm{Ni}$ in plant tissues and insect gall of lowbush blueberry, Vaccinium augustifolium, near an ore smelter at Sudbury, Ontario,

Canada. Canadian Journal of Botany 69(7):14831490.

Baker, A J M (1987). Meta tolerance. New Phytologist 106:93-111.

Baker, A J M; Walker, P L (1990). Ecophysiology of metal uptake by tolerant plants. In: Shaw,A J (Ed.), Heavy metal tolerance in Plants. CRC Press, Boca Raton. pp.155-178.

Bengtsson, S; Tyler, G (1976). Vanadium in the environment - a technical report. Monitoring and Assessment Research Centre, University of London.

Dahmani-Muller, H; van Oort, F; Gelie, B; Balabane, M (2000). Strategies of heavy metal uptake by 
three plant species growing near a metal smelter. Environmental Pollution 109: 231-238.

De Vos, C H R; Schat, H; De Waal, M A M; Voojs, R ; Ernst W H O (1991). Increased resistance to copper-induced damage of root cell plasmalemma in copper tolerant Silene cucubalus. Physiologia Plantarum 82: 523-528

Epstein, E (1972). Mineral nutrition of plants: principles and perspectives. John Wiley and Sons Inc., New York.

Hutchinson, T C; Whitby, L M (1974). Heavy metal pollution in the Sudbury mining and smelting region in Canada. I. Soil and vegetation contamination by nickel, copper and other metals. Environmental Conservation 1:123-132.

Jarvis, M D; Leung, D W M (2002). Chelated lead transport in Pinus radiata : an ultrastructural study. Environmental and Experimental Botany 48:21-32.

Koeppe, D E (1981). Lead : understanding the minimal toxicity of lead in plants. In: Effect of heavy metal pollution on plants. Vol. 1 (Effect of trace metals on plant functions). Edited by N.W. Lepp. Applied Science Publishers, London. Pp. 55-76.

Li, X.; Feng,Y; Sawatsky, N (1997). Importance of soil-water relations in assessing the endpoint of bioremediated soils. I. Plant growth. Plant and Soil 192:219-226.

Malallah, G; Afzal, M; Gulshan, S; Abraham, D; Kurian, M; Dhami, M S I (1996). Vicia faba as bioindicator of oil pollution. Environmental Pollution 92: 213-217.

Miller, R J; Koeppe, D E (1971). Accumulation and physiological effects of lead in corn. In: Proceedings of University of Missouri, Columbia 4,pp.186-193.

Monni, S; Salemaa, M; White, C; Tuittila, E; Huopalainen, M (2000). Copper resistance of Calluna vulgaris originating from the pollution gradient of a $\mathrm{Cu}-\mathrm{Ni}$ smelter in southwest

Finland. Environmental Pollution 109: 211-219.
Odjeba, V J; Sadiq A O (2002). Effects of spent engine oil on the growth parameters, chlorophyll and protein levels of Amaranthus hybridus L. The Environmentalist 22:23-28.

Ogunkunle, S (1983). NIFOR soil report. Journal of the Nigerian Institute For Oil Palm Research 6(23): 234-255.

Orhue, E R; Osaigbovo, U A (2003). Effects of spent engine oil on some soil chemical characteristics and performance of Dialium guineense seedlings. Nigerian Journal of Science 21: 44-49.

Peterson, P J; Girling, C A (1981). Other trace metals. In: Effect of heavy metal pollution on plants. Vol. 1. (Effects of trace metals on plant functions). Edited by N.W. Lepp. Applied Science Publishers, London. pp. 213-278.

Pichtel, J; Kuroiwa, K; Sawyerr, H J (2000). Distribution of $\mathrm{Pb}$ and $\mathrm{Ba}$ in soils and plants of two contaminated sites. Environmental Pollution 10:171-178.

Pichtel, J; Salt, C A (1998). Vegetative growth and trace metal accumulation on metalliferous wastes. Journal of Environmental Quality 27:618-624.

Reeves, R; Baker, A J M (2000). Metal accumulating plants. In: Raskin, I., Ensley, B.D. (Eds). Phytoremediation of toxic metals: using plants to clean up the environment. John Wiley and Sons Inc., New York. pp.193-229.

Salim, R; Al-Subu, M M; Atallah, A (1993). Effects of root and foliar treatments with lead, cadmium and copper on the uptake, distribution and growth of radish plants. Environment International 19:393-404.

Whismann, M L; Geotzinger, J W; Cotton, F O (1974). Waste lubricating oil research. In: An investigation of several re-refining methods. Bureau of Mines, Bartlesville Energy Research Centre. 352p.

Zurayk, R; Sukkariyah, B; Baalbaki, R (2001). Common hydrophytes as bioindicators of nickel, chromium and cadmium pollution. Water, Air and Soil Pollution 127:373-288. 